\title{
On Effects of Market Integration on Technology Choice
}

\author{
Ryoichi Nomura \\ Ritsumeikan University
}

\begin{abstract}
In this paper, we investigate how market integration affects firms' technology choices. Although market integration encourages cost-reducing research and development $(R \& D)$ investments in many cases, it may discourage it in two cases: (1) when market sizes are quite different and the effects of $R \& D$ are not so high, market integration may discourage $R \& D$ in a large country; and (2) if the firm in a large country only invests in the segmented market, market integration may discourage $R \& D$ in a large country, while encouraging it in a small country. These results correspond to data about $R \& D$ intensities in European Union countries.
\end{abstract}

- JEL classification: F02, F15, L13, O31

- Keywords: Market Integration, Technology Choice, Cournot Competition

\section{Introduction}

Recently, movements towards market integration or negotiations for free trade areas have been more active. The obvious example is the European Union (EU); however, many other countries and regions have tried creating free trade areas, as in the current discussions between Japan and Korea. Market integration increases market size, and thereby firms facilitate to compete in various aspects: for example, advertisements, production expansion to exploit scale economies, and improved product quality. From this point of view, market integration seems to intensify

\footnotetext{
*Corresponding address: Graduate School of Economics, Ritsumeikan University, 1-1-1 Noji-Higashi Kusatsu, Shiga 525-8577, Japan. Tel +81-77-561-3940, Fax +81-77-561-3947, E-mail: ec553920@ec. ritsumei.ac.jp (C2006-Center for International Economics, Sejong Institution, All Rights Reserved.
} 
firms' research and development (R\&D) activities.

However, as shown in Table 1, taking the EU as an example, market integration does not necessarily intensify firms' R\&D activities. Although gross domestic expenditures on R\&D as a percentage of GDP increased after 1992 in some countries, it decreased in others (i.e., Germany, Italy, and United Kingdom). This raises the question: under what kinds of conditions do market integration discourage firms' R\&D activities?

Many researchers have tackled the effects of market integration for oligopoly markets. Taking economic integration as the form of reductions in the cost of trade, Venables (1990) analyzed whether market integration increases the social welfare of the market ${ }^{1}$. Wright (2003) analyzed whether markets are integrated or segmented endogenously, and showed that policy-makers choose to segment markets through their choice of tariffs. Ishikawa (2004) examined how a movement from segmented markets to integrated markets affects the volume of trade, consumer prices, profits and welfare in a monopoly model. Lommerud and Sørgard (2001) and Colonescu and Schmitt (2003) analyzed the effects of market

Table 1. Average Gross Domestic Expenditure on R\&D as a percentage of GDP

\begin{tabular}{|c|c|c|c|c|c|}
\hline COUNTRY & 1985-1992 & 1993-2004 & COUNTRY & 1985-1994 & 1995-2004 \\
\hline Belgium & 1.625 & 1.987 & Austria & 1.381 & 1.927 \\
\hline Denmark & 1.468 & 2.068 & Finland & 1.904 & 2.989 \\
\hline France & 2.290 & 2.259 & Sweden & 2.866 & 3.703 \\
\hline Germany & 2.669 & 2.364 & & & \\
\hline Greece & 0.325 & 0.882 & & & \\
\hline Ireland & 0.854 & 1.228 & & & \\
\hline Italy & 1.200 & 1.059 & & & \\
\hline Luxembourg & - & 1.710 & & & \\
\hline Netherlands & 2.050 & 1.964 & & & \\
\hline Portugal & 0.478 & 0.696 & & & \\
\hline Spain & 0.713 & 0.839 & & & \\
\hline United Kingdom & 2.155 & 1.899 & & & \\
\hline
\end{tabular}

Note: The number in each cell corresponds to average in each period.

Source: OECD, Main Science and Technology Indicators, November 2004.

${ }^{1}$ In addition to theoretical analysis, Venables (1990) provided some numerical analysis of the possible effects of completion of the internal market in the European Community. 
integration on firms' collusive behavior.

One unsolved problem in the oligopoly model remains - what are the effects of market integration on the intensity of R\&D activity? We try to answer this question by using an extended model of Mills and Smith (1996)'s one.

Mills and Smith (1996) considered firms' technology choice and analyzed a desirability of technology choice from the viewpoint of social welfare in a twostage Cournot duopoly game. In the first stage, firms choose technology between old technology (with high marginal costs and low fixed costs) and new technology (with low marginal costs and high fixed costs). In the second stage, firms compete à la Cournot $^{2}$. In their paper, cost-reducing $\mathrm{R} \& \mathrm{D}$ investments enable the firms to use new technology. In other words, the firms can use more effective technology if they make cost-reducing R\&D investments.

In this paper, we assume that there are two countries and each country has one firm. The firms are ex ante symmetric and producing a homogenous good. The firms face the following two-stage game. In the first stage, each firm determines whether it undertakes a production cost-reducing $R \& D$ investment. If it undertakes $\mathrm{R} \& \mathrm{D}$, it then adopts a new technology; if it does not, it adopts an old technology. In the second stage, the firms produce a homogenous good using the technology chosen to supply the market. Note that when two markets are segmented, each firm supplies to its local market. On the other hand, when the two markets are integrated, the firms are forced to competea la Cournot in the integrated market. We refer to the former as the segmented market case, and to the latter as the integrated market case.

Three main results were established. Firstly, when market sizes are quite different and the effects of cost-reducing R\&D investments are not so high, market integration discourages firms' R\&D activities in a large country. Secondly, when technology choice is simultaneous and only one firm invests in cost-reducing R\&D in a segmented market case, market integration may discourage R\&D investment in a large country and may encourage it in a small country; sequential technology choice eliminates this possibility. Thirdly, market integration encourages R\&D activities under certain situations.

The rest of this paper is organized as follows. Section 2 constructs the model, and Section 3 presents the preliminary results. In Section 4, an analysis is made of the effects of market integration on firms' $R \& D$ activity by comparing the

${ }^{2}$ Elberfeld (2003) generalized the model of Mills and Smith (1996) by examining an industry with more than two firms. Elberfeld and Nti (2004) introduced uncertainty to the model of Elberfeld (2003). 
segmented market case with the integrated market case. Section 5 concludes the paper.

\section{The Model}

There are two countries, denoted by $X$ and $Y$. Firm $x$ and Firm $y$ belong to country $X$ and country $Y$, respectively. Both firms are assumed to produce a homogeneous good. Demand functions of each country's market are given by

$$
\begin{gathered}
Q_{X}=b\left(1-p_{X}\right), \text { and } \\
Q_{Y}=(1-b)\left(1-p_{Y}\right),
\end{gathered}
$$

where $p_{j}$ is the price of market $j, Q_{j}$ is the quantity demanded in market $j$, and $b$ is a positive parameter represented by market $X$ 's size, where $j=X, Y$. We assume that market $X$ is no smaller than market $Y$, that is $b \in[0.5,1)$, and refer to country $X$ (country $Y$ ) as a large country (small country) from the viewpoint of market size.

Each firm faces the following two-stage game. In the first stage, each firm determines whether it undertakes a production cost-reducing R\&D investment. If it undertakes $\mathrm{R} \& \mathrm{D}$, then it adopts a new technology called technology $B$, the total cost of which is $C_{i B}$; alternatively, it adopts an old technology called technology $A$, the total cost of which is $C_{i A}$. Each technology can be described as

$$
\begin{aligned}
& C_{i A}=c\left(q_{i X}+q_{i Y}\right), \text { and } \\
& C_{i B}=F,
\end{aligned}
$$

where $q_{i j}$ is firm i's output in market $j, c \in(0,0.5)$ is the positive and constant marginal cost, and $F$ is a fixed cost of $\mathrm{R} \& \mathrm{D}$ investment. In the second stage, each firm produces a homogenous good using the technology chosen, and monopolizes the market where it belongs in the segmented market case; alternatively, the firms are forced to competeá la Cournot in the integrated market case.

\section{Preliminary Results}

To investigate effects of market integration on technology choice, we solve the first-stage subgame under the segmented market case and the integrated market case. 


\section{A. Segmented market case}

In the segmented market case, from equations (1), (2), and (3), firm $i$ 's quantity supplied and profit are

$$
q_{i A}=\frac{(1-c)}{2} b, q_{i B}=\frac{1}{2} b, \pi_{i A}=\frac{(1-c)^{2}}{4} b, \text { and } \pi_{i B}=\frac{1}{4} b-F,
$$

where subscript $A(B)$ represents technology $A(B)$. From equations (4), we have the following results:

Lemma 1: There are two critical values $F_{x}^{S}$ and $F_{y}^{S}$, that is,

$$
\begin{aligned}
& F_{x}^{S}=\frac{1}{4} b c(2-c), \text { and } \\
& F_{y}^{S}=\frac{1}{4}(1-b) c(2-c),
\end{aligned}
$$

where superscript $S$ represents the segmented market case. If $F<F_{x}^{S}\left(F_{y}^{S}\right)$, then firm $x$ (firm $y$ ) invests and uses a new technology in a large country (small country).

Lemma 2: $F_{x}^{S} \geq F_{y}^{S}$ for $\forall b \in[0.5,1]$ and $\forall c \in(0,0.5)$.

Lemma 2 indicates that, in the segmented market case, if small country firm $y$ uses a new technology, then large country firm $x$ also uses a new technology.

\section{B. Integrated market case}

Supposing that all trade barriers are removed and the two markets are integrated; from equations (1), (2), and (3), firm $i$ 's quantity supplied in the integrated market can be expressed as

$$
q_{i A A}=\frac{1}{3}(1-c), q_{i B B}=\frac{1}{3}, q_{i B A}=\frac{1}{3}(1+c), \text { and } q_{i B A}=\frac{1}{3}(1-2 c),
$$

where the subscript $A A(B B)$ represents the case where both firms adopt technology $A$ $(B)$, and the subscript $A B$ represents the case where firm $x$ (firm $y$ ) adopts technology $A(B)$. Firm $y$ 's quantities in each choice of technology can be similarly derived from equations (1), (2), and (3). Note that, for simplicity, we assume that 
there are no transportation costs.

From equations (1), (3), and (7), firm $i$ 's profits in equilibrium are given by

$$
\pi_{i A A}=\frac{1}{9}(1-c)^{2}, \pi_{i B A}=\frac{1}{9}(1+c)^{2}-F, \text { and } \pi_{i A B}=\frac{1}{9}(1-2 c)^{2} .
$$

From equation (8), we have following results:

Lemma 3: Suppose that the markets are integrated.

(i) No firms invest for R\&D if $F>F_{01}$.

(ii) Only one firm undertakes R\&D activity if $F_{01}>F>F_{12}$.

(iii) Both firms use a new technology if $F_{12}>F$.

Both $F_{01}$ and $F_{12}$ are critical values where

$$
\begin{gathered}
F_{01}=\frac{4}{9} c \text { and } \\
F_{12}=\frac{4}{9} c(1-c) .
\end{gathered}
$$

Lemma 4: $F_{01}>F_{12}$ for $\forall b \in[0.5,1)$ and $\forall c \in(0,0.5)$.

\section{Analysis}

In this section, we investigate how market integration affects firms' technology choice. In doing so, we compare firms' technology choice in the segmented market case with that in the integrated market case.

First, let us compare each critical value about $R \& D$ investments. From equations (6) and (10), together with Lemma 2, we obtain

Lemma 5: $F_{12}>F_{y}^{s}$ for $\forall b \in[0.5,1)$ and $\forall c \in(0,0.5)$.

Lemma 5 states that if firm $y$ uses a new technology in the segmented market then both firms use a new technology in the integrated market. From equations (5), (9), and (10), we have 
Figure 1. Parameter Regions and the magnitude relationship between $F_{x}^{a}$ and $F_{12}$.

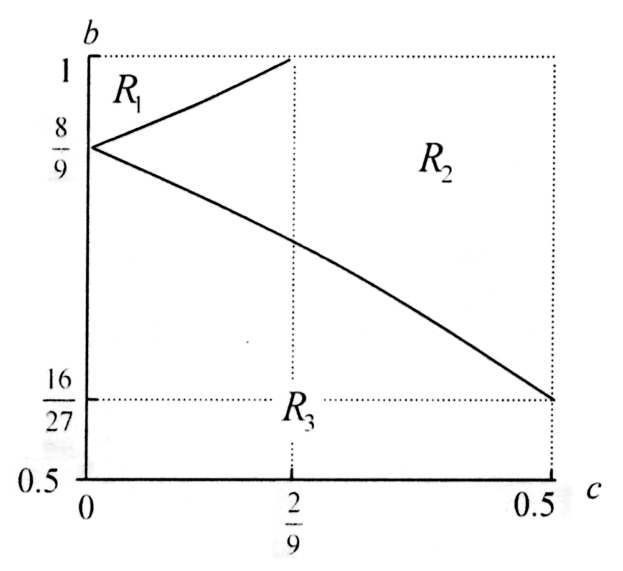

\section{Lemma 6:}

(i) If $1>b>\frac{8}{9}$ and $\frac{2(9 b-8)}{9 b}>c>0$, then $F_{x}^{S}>F_{01}$; otherwise, $F_{x}^{S}<F_{01}$.

(ii) If $\frac{8}{9}>b>\frac{16}{27}$ and $\frac{1}{2}>c>\frac{2(9 b-8)}{9 b-16}$ or $1>b>\frac{8}{9}$, then $F_{x}^{S}>F_{12}$;

otherwise, $F_{x}^{S}<F_{12}$.

Figure 1. represents these results. From Lemmas 1, 3 and 6 , if $1>b>\frac{8}{9}$ and $\frac{2(9 b-8)}{9 b}>c>0$, i.e., the combination $(\mathrm{b}, \mathrm{c})$ is in $\mathrm{R}_{1}$ in Figure 1, then $F_{x}^{S}>F>F_{01}$. It means that although large country firm $x$ solely invests in the segmented market case, neither firms do in the integrated market case. We summarize

Proposition 1: Market integration discourages R\&D investments if $F_{x}^{S}>F>F_{01}$.

Proposition 1 states that market integration discourages R\&D activity in the large country when the scales of markets are quite different between the two markets and the effects of cost-reducing R\&D investment are not so high. In this case, although the firm in the large country has an incentive to invest in the segmented market, no firms invest in the integrated market.

The intuition behind Proposition 1 is as follows. Market integration has two effects on firms' R\&D decisions; an expansion of the existing market and the 
emergence of a rival firm. The former has the effect of increasing firms' outputs, while the latter decreases outputs. When sizes of markets are enormously different between the two markets, the effects of market expansion are not significant for a firm in the large country. In this situation, the effect of the emergence of a rival firm dominates that of market expansion for that firm. In addition to this, when the effect of cost-reducing R\&D investment is low, a firm in the large country does not pay $R \& D$ expenditures even though there is an incentive to invest in the segmented market case.

Next we consider the possibility that only one firm invests in the segmented market case, while another firm solely does in the integrated market case.

Lemma 3 (ii) indicates that there are two equilibria in the integrated market case if $F_{01}>F>F_{12}$ : where either firm $x$ or firm $y$ uses a new technology. In addition, if $F_{x}^{S}>F>F_{y}^{S}$, only firm $x$ uses a new technology in the segmented market case. Under these circumstances, market integration may discourage the adoption of a new technology, even though it does not change the number of investing firms. In other words, in this situation, market integration may discourage R\&D activity in the large country and may encourage it in the small country. Therefore, we obtain

Proposition 2: Market integration may discourage $R \& D$ activities if $\min \left[F_{x}^{S}, F_{01}\right]>F>F_{12}$.

Proposition 2 states that there is the possibility that only firm invests in the segmented market case, while another firm solely dose in the integrated market case. Proposition 2 implies that whether market integration discourages firms' R\&D depends on the timing of technology choice in the above situation. Now, let us consider the case of sequential technology choice. Note that in situations where both firms invest or neither firm invests in R\&D in the integrated market, the sequential technology choice does not affect firms' R\&D decisions. Therefore, We focus on the situation where the firm in the large country (small country) has an (no) incentive to invest in the segmented market case, whereas only one firm invests in the integrated market case (i.e., $F_{x}^{S}>F>F_{y}^{S}$ and $F_{01}>F>F_{12}$ ). Suppose that the firms choose technology sequentially in the integrated market, and that firm $x$ (in the large country) chooses its technology before firm $y$. Whether firm $x$ invests in the integrated market depends on the magnitude relationship between $\pi_{x B A}$ and $\pi_{x A B}$, from equations (5), (6), (8), (9), and (10), $\pi_{x B A}>\pi_{x B A}$. From here, we have following result: 
Remark: Suppose that technology choice is sequential, and that at least one firm invests in the segmented market case. Market integration does not discourage firms' R\&D activity unless market sizes are not vastly different and the effects of R\&D investment are not so high.

Finally, We consider the situation where market integration encourages firms' R\&D investments. From Lemmas 2 and 4, we establish following results:

Proposition 3: Market integration encourages firms' R\&D activities in the following ways.

(i) Market integration increases the number of investing firms from zero to one, if $F>F_{x}^{S}$ and $F_{01}>F>F_{12}$.

(ii) Market integration increases the number of investing firms from zero to two, if $F>F_{x}^{S}$ and $F_{12}>F$.

(iii) Market integration increases the number of investing firms from one to two, if $F_{x}^{S}>F>F_{y}^{S}$ and $F_{12}>F$.

Now, let $m(n)$ represent the number of firms which engage in R\&D activity in the segmented market (integrated market) case; We refer to changes in the number of investing firms from $m$ to $n$ as $(m, n)$-case. Depending on the level of $F,(0,1)$ case may occur in regions $R_{2}$ and $R_{3}$ in Figure $1,(0,2)$-case may occur in region $R_{3}$, and $(1,2)$-case may occur in all regions. Note that $(1,2)$-case never occurs in a symmetric market case. Proposition 3 says that market integration may encourage $R \& D$ activity drastically, which means that it increases the number of investing firms from zero to two. It is a contrast to the results of Propositions 1 and 2, that is market integration may decreases the number of investing firms at most only one.

\section{Concluding Remarks}

We have investigated how market integration affects firms' technology choice using an extended model of Mills and Smith (1996)'s. The main conclusions drawn from this are as follows. Firstly, when market sizes are quite different and the effects of cost-reducing R\&D investment are not so high, market integration discourages firms' R\&D activity. Secondly, if technology choice is simultaneous and only one firm chooses a new technology in the segmented market case, market integration may discourage R\&D investment in a large country and may encourage it in a small country. Sequential technology choice eliminates this possibility. 
Thirdly, market integration encourages R\&D activities under a broader range of parameters $(c, F)$.

These results correspond to the data about R\&D intensities in EU countries. As shown in Table 1, the intensity of R\&D investment in the EU seems to have increased in relatively small countries; whereas it seems to have decreased in relatively large countries (i.e., Germany, Italy, and United Kingdom) after 1992. Proposition 1 indicates that market integration discourages R\&D investment in the larger country when market sizes are quite different, and Proposition 2 implies that market integration may discourage R\&D investment in the large country and may encourage it in the small country under certain situations. Therefore, the model in this paper can be regarded as one explanation as to why market integration discourages firms' R\&D investment.

\section{Acknowledgments}

An earlier version of this paper was presented at the annual meeting of the Japanese Economic Association (2005, June). We are grateful to Masahiro Ashiya, Jota Ishikawa, Hiroshi Kurata, Takao Ohkawa, Masayuki Okawa, Makoto Okamura, Tetsuya Shinkai, Ryuhei Wakasugi, and Chisato Yoshida for their valuable comments and suggestions. Of course, any remaining errors are ours.

Received 20 April 2006, Accepted 10 June 2006

\section{References}

Colonescu, RC., Schmitt, N. (2003), Market Segmentation, Market Integration, and Tacit Collusion, Review of International Economics, 11(1), 175-192.

Elberfeld, W. (2003), "A Note on Technology Choice, Firm Heterogeneity and Welfare", International Journal of Industrial Organization, 21, 593-605.

Elberfeld, W., and Nti, K.O. (2004), "Oligopolistic Competition and New Technology Adoption under Uncertainty", Journal of Economics, 82(2), 105-121.

Ishikawa, J. (2004), "From Segmented Markets to Integrated Markets: an Analysis of Economic Integration and Antidumping Legislation", Review of International Economics, 12(4), 706-722.

Lommerud, K.E., and Sørgard, L. (2001), "Trade Liberalization and Cartel Stability", Review of International Economics, 9(2), 343-355.

Mills, D.E., and Smith, W. (1996), "It Pays to be Different: Endogenous Heterogeneity of Firms in an Oligopoly", International Journal of Industrial Organization, 14, 317 - 
329.

OECD (2004), Main Science and Technology Indicators, November.

Venables, A.J. (1990), "The Economic Integration of Oligopolistic Markets", European Economic Review, 34, 753-773.

Wright, D.J. (2003), "Some Economics of Integrated and Segmented Markets", Review of International Economics, 11(1), 72-89.

\section{Mathematical Appendix}

\section{Proof of Proposition 1}

First, consider the case where market sizes are symmetric, that is $b=0.5$. From Lemma $2, F_{x}^{S}=F_{y}^{S}$ in this case. From equations (5) and (10), we have

$$
F_{x}^{S}-F_{12}=\frac{(2-c) c}{4} b-\frac{4(1-c) c}{9}<0,
$$

because of $c \in(0,0.5)$. The above inequality implies that market integration never discourages $R \& D$ activities in this case.

Second, consider an asymmetric case, that is $b>0.5$. In this case, the condition that $F_{x}^{S}>F_{y}^{S}$ is obviously satisfied from Lemma 1. Discouragement of R\&D activities occurs if and only if $F_{x}^{S}>F>F_{01}$. From equations (5) and (9), we have

$$
F_{x}^{S}-F_{01}=\frac{(2-c) c}{4} b-\frac{4 c}{9}=\frac{c(9 b(2-c)-16 c)}{36} .
$$

(A-1) is positive if the condition where

$$
c<\frac{2(9 b-8)}{9 b}
$$

is satisfied. Note that this condition holds if and only if $b>\frac{8}{9}$, because $c$ is nonnegative.

Q.E.D. 